\title{
RURAL HUMAN CAPITAL AS A DETERMINANT OF ECONOMIC DEVELOPMENT
}

Edyta BOMBIAK, Faculty of Economic and Legal Sciences, Siedlce University of Natural Sciences and Humanities, Konarskiego 2 , 08-110 Siedlce, Poland, edyta.bombiak@uph.edu.pl

Adam MARCYSIAK, Faculty of Economic and Legal Sciences, Siedlce University of Natural Sciences and Humanities, Konarskiego 2,08-110 Siedlce, Poland, adam.marcysiak@ uph.edu.pl (corresponding author)

Human capital is an economic category which is increasingly applied in the models of economic growth and development. Many studies have demonstrated its positive effect on economic development at the national and regional levels. The level of development of rural areas is also strongly correlated with the human factor. The objective of the study was to carry out a quantitative and qualitative diagnosis of the situation of human capital across rural areas in Poland and to indicate the main challenges associated with the shaping of this capital in the context of economic growth simulation. The method used to meet the objective was a review of source literature and an analysis of statistical data from the Central Statistical Office (GUS) with the application of dynamics and structure indices. In the course of research, it was established that the main trends affecting the situation of human resource capital across rural areas in Poland are: the ageing of the rural population, as a dominant negative trend, and a systematic, though slow, increase in the level of education, as a dominant positive trend. It was determined that unfavorable demographic transformations of rural communities involve the risk of limiting economic activities of the elderly, and at the same time, also a decrease in their economic independence and an increase in the social burden resulting therefrom. On the other hand, the observed rise in the level of education and economic activity may accelerate the beneficial transformations of the area structure of agricultural farms, for it contributes to the acceleration of migration of the rural population to other, nonagricultural professions. In this context, taking actions, both nationally and regionally, aiming at increasing qualifications of rural (including agricultural) populations constitutes a vital opportunity, which increases intellectual potential and competitive ness across the country and its individual regions.

Keywords: human capital, rural areas, economic development

\section{INTRODUCTION}

Rural areas include the territory situated outside administrative borders of towns and cities and comprise rural or rural-urban communes. In Poland, rural areas make up more than $90 \%$ of the country and are inhabited by nearly $40 \%$ of the Polish population. They fulfill a number of functions, both regarding agricultural and non-agricultural production, and the creation of public goods (Chechelski et al., 2012). Therefore, they are of utmost importance from the economic, social and environmental points of view.

The socio-economic development of rural areas is a derivative of a very large number of factors, with human factor playing an essential role (Becker, 1993). The structure of regional development is a derivative of knowledge and human activity and initiatives undertaken by people. It is possible to adapt more swiftly to the changing economic conditions thanks to suitable qualifications and their proper use.

Rural human capital is perceived as one of the key factors promoting growth and affecting the multifunctional development of rural areas in Poland. As such, it constitutes a vital research area. The objective of the study was to carry out a quantitative and qualitative diagnosis of the situation of human capital across rural areas in Poland and to indicate the main challenges associated with the shaping of this capital in the context of economic growth stimulation. In the course of research, the following problems were addressed:

- What is the role of human capital in the process of economic growth stimulation?

- What human capital resources, both in terms of quantity and quality, can be found across rural areas in Poland?

- What changes in terms of the size of rural human capital in Poland are to occur by the middle of the 21 st century?

- What are the key challenges resulting from the analysis of the situation and changes in human capital resources across rural areas in Poland?

Copyright (C) 2017 The Authors. Published by Aleksandras Stulginskis University. This is an open-access article distributed under the terms of the Creative Commons Attribution License (CC-BY 4.0), which permits unrestricted use, distribution, and reproduction in any medium, provided the original author and source are credited. 


\section{RESEARCH METHODS}

The method used to meet the objective was a review of source literature and an analysis of statistical data from the Central Statistical Office (GUS) with the application of dynamics and structure ratios.

The analyses have both a cognitive value, involving an acquisition of sound and deep knowledge regarding rural human capital, and a practical value, for the results can be applied to government's and self-governments' actions to develop instruments contributing to the improvement of rural human capital quality and its better use to stimulate their economic growth.

\section{IMPORTANCE OF HUMAN CAPITAL FOR ECONOMIC DEVELOPMENT}

Human capital can be considered in two ways. In a narrow sense, it is defined as the knowledge, skills, competencies and attributes embodied in individuals that facilitate the creation of personal, social and economic wellbeing (OECD, 2007). It is unique, multidimensional, and indelibly linked with men. Although it may not be marketed, it can be produced or increased by investment. In a broad sense, human capital means "the knowledge, skills, health and energy resources found in the society" (Domański, 1993). It is the foundation of social capital creation (Fukuyama, 1997, p.20) and an important element of society's innovative potential. Moreover, human capital determines technical progress and the creation of new solutions, the adaptation capacity of the regions, capital inflow, the rate of structural transformations, and acceleration of the regional convergence processes (Caroleo, Pastore, 2010).

Interest in the effect of human skills and knowledge on the nation's well-being dates back to the beginnings of the economic thought. However, this knowledge had not been aligned or well established until the 60s, when the theory of human capital originated. The concept of human capital as a growth factor may be found in neoclassical theories of economic growth (Solow, 1956; Mankiw et al., 1992) and the theories of endogenous economic growth (Crafts, 1996). Empirical research, drawing inspiration from the endogenous growth theory, highlights that human capital (education, abilities, health) determine not only the productivity of work, but also the accumulation of other generation capacities, including most of all scientific and technical knowledge and physical capital (Romer,1990; Rogers, 2003). The results of empirical analyses confirm that in the countries with the lowest level of education and population's health, the achievement of sustainable development takes much longer than elsewhere (Sachs, 2001, p.24). Benhabib and Spiegel (2005) prove that human factor is not only a production factor but also an innovative technology booster. The concentration of human capital in urbanized regions is a factor attracting foreign capital to advanced sectors, reducing the costs of restructuring (Jurajda and Terrell, 2009).

Human capital may also be seen as a crucial factor of regional development. The role of innovation, knowledge and the human factor has been strongly stressed in the theory of regional innovation systems (Cooke, 1992) and the theory of the learning regions (Storper, 1995). They assume that the key factors of regional competitiveness are knowledge, creativity, and inhabitants' ability to learn and create innovations. As often emphasized in subject literature, the gaps in the level of economic development between the rural and urban areas may result from disparities in human capital (Bollman, 1999), which may in part be a consequence of young people, possibly embodying a relatively high human capital, migrating to cities (Lucas, 2004). The level of human capital development determines the ability to acquire and implement the world's achievements in the field of science and philosophy. Moreover, it affects institutional transformations, favors the propagation and popularization of modern patterns of consumption and shapes the modern technological, organizational, social and IT infrastructure, and the like. Thus, human capital investment brings positive effects to both individuals and the society as a whole. Whereas human capital underinvestment contributes to the creation of civilizational and educational gaps, the intensification of the processes of alienation, threatening to stagnate the economy, or the increase in the emigration of highly qualified human capital, are detrimental for the country's economy (Makowski, 2002).

All in all, many studies highlight the immense influence of the size, structure and quality of human capital on the development of communities, regions, and whole economies. What is most often underlined is the relation between human capital development and the level of innovation in the economy.

\section{RURAL HUMAN CAPITAL RESOURCES IN POLAND}

The situation of Polish human resources, including rural population, is affected by trends regarding births, deaths, and internal and external migrations. The analysis of changes in human capital resources between 1988 and 2015 is presented in Table 1. According to the Central Statistical Office (GUS), in the year 2015, 39.7\% of the Polish population (i.e. 15.2 million people) inhabited rural areas. With respect to the year 1988, the number of people increased by nearly 554,000 . The rise in the rural population was mainly the result of a positive internal migration balance. The migration of people from the towns and cities to the countryside was greater than from the countryside to the towns and cities (Frenkel, 2016). Therefore, in recent years there has been an increase in the number of people inhabiting rural areas, which has been especially dynamic in the vicinity of large urban agglomerations.

As far as the structure of the rural population by age groups in the years 1988-2015 is concerned, a drop in the pre-working age population (from $30.9 \%$ to $19.7 \%$ ) coincided with a rise in the post-production age population (from $14.6 \%$ to $17.0 \%$ ). The age situation of the rural population is better than that of the urban population, as demonstrated by the fact that the share of people aged 18-44 increased in the analyzed period from $37.2 \%$ to $40.3 \%$. An increase in the 
younger, pre-working age group correlated with both demographic shifts (the 70s baby boom generation entering the production age) and the positive balance of migration of the urban population to the countryside. Despite that the process of population ageing in Poland, including rural population, is one of the least advanced across all European Union member states, the years to come will seriously accelerate it.

Table 1. Numbers and structure of the Polish population by age and place of residence between 1988-2015

\begin{tabular}{|c|c|c|c|c|c|}
\hline \multirow[b]{2}{*}{ Population } & \multicolumn{2}{|c|}{ Population (as of $31 \mathrm{Dec})$} & \multicolumn{3}{|c|}{ Population structure by age (in \%) } \\
\hline & in million & in $\%$ & pre-working & working & post-working \\
\hline City/Town 1988 & 23.187 & 61.2 & 29.2 & 59.6 & 11.2 \\
\hline 1995 & 23.876 & 61.8 & 26.4 & 59.9 & 13.7 \\
\hline 2000 & 23.876 & 61.8 & 22.2 & 63.6 & 14.2 \\
\hline 2005 & 23.452 & 61.4 & 18.6 & 66.0 & 15.4 \\
\hline 2010 & 23.448 & 60.8 & 17.1 & 65.3 & 17.6 \\
\hline 2015 & 23.203 & 60.3 & 16.7 & 62.0 & 21.3 \\
\hline Countryside 1988 & 14.698 & 38.8 & 30.9 & 54.5 & 14.6 \\
\hline \begin{tabular}{|r|}
1995 \\
\end{tabular} & 14.733 & 38.2 & 29.7 & 54.1 & 16.2 \\
\hline 2000 & 14.768 & 38.2 & 27.1 & 57.4 & 15.5 \\
\hline 2005 & 14.710 & 38.6 & 23.8 & 60.0 & 15.4 \\
\hline 2010 & 15.068 & 39.2 & 21.5 & 63.1 & 15.4 \\
\hline 2015 & 15.252 & 39.7 & 19.8 & 63.2 & 17.0 \\
\hline
\end{tabular}

Source: Own calculations based on Rocznik statystyczny 2001 (Statistical Yearbook 2001) GUS, Warszawa 2001, tab. 119, 120, Rocznika Demograficznego 2016 (Demographic Yearbook 2016), GUS, Warszawa 2016. p. 162.

In line with the demographic projection drafted by GUS, by 2050 there will be an ongoing population loss both in the cities/towns and in the countryside (Table 2). In the years 2020-2050, the total population of Poland will decrease by $4,187,300$ people, $7.1 \%$ of which will be attributed to the rural population. A particularly unfavorable situation will be that of people at working age. In the years 2020-2050, the above age group will shrink across Poland by as much as $4,772,300$ people. The share of rural areas in the cited drop will be $23.5 \%$. Even though population ageing, both urban and rural, appears with varying intensity, it will result in shifts between various economic age groups.

Table 2. Projection of Polish population shifts by age and place of residence between 2015-2050

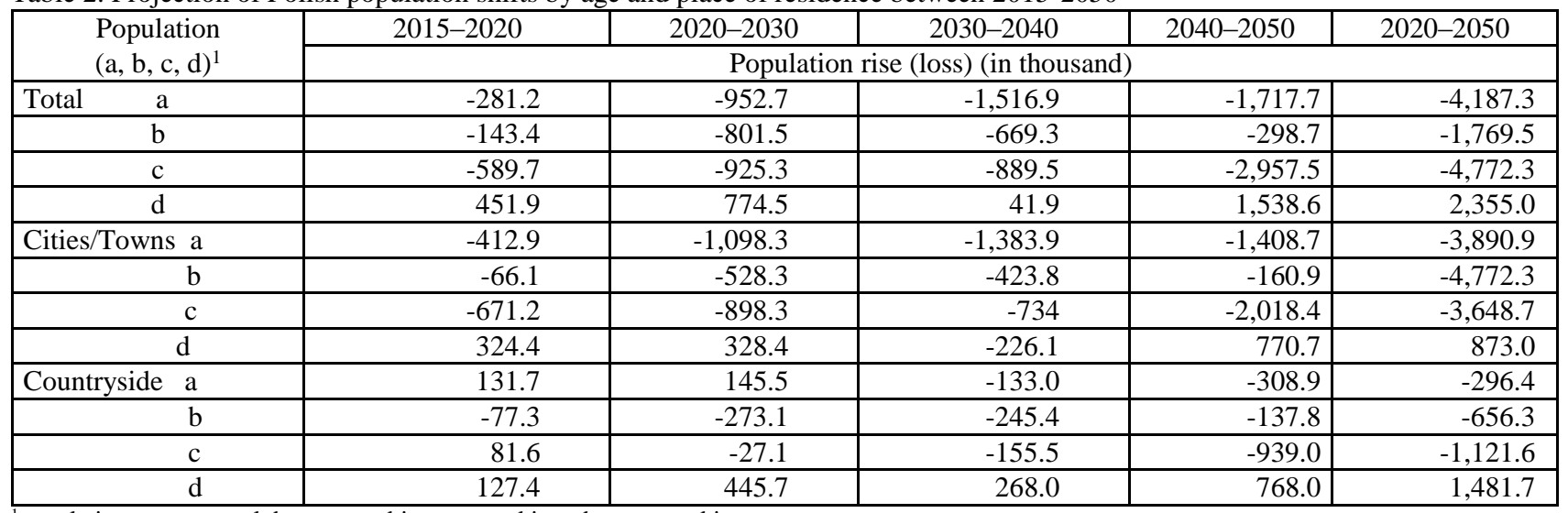

${ }^{1}$ population age: a - total, b - pre-working, c - working, $\mathrm{d}$ - post-working;

Source: own calculations based on Prognozy ludności Polski na lata 2004-2050. (Projection of Polish population for the years 2004-2050.) GUS, Warszawa 2014.

In view of the above, demographic projections for Poland forecast a gradual increase in the rate of ageing of the rural population. This will be expressed by a decreasing number of working age and an increasing number of post-working age population. This process is a direct consequence of a drop in birth and death rates (Reher, 2004) and internal migration processes (between the city/town and the countryside). What is significant for the intensification of the process of rural population ageing is thriving "silver tourism" (Zsarnòczky, 2016). The reason why the percentage of the elderly across rural areas is growing is that attractive, scenic rural areas of hospitable climate are more and more often becoming a popular target destination (Avramov, Maskova, 2003).

Both the size of the demographic parameters of ageing and the direction of said changes indicate that the process is becoming deeper and irreversible. An analysis conducted by American demographers Clark and Spengler demonstrated that government spending per one older person was markedly higher than government spending per one younger person (Clerk, Spengler, 1985). The authors highlight that expenditure related to older people includes mainly the cost of living and does not affect the productive potential of the economy. Hence, population ageing involves an increase in social economic burden, a decrease in the share of active population, a growing demand for health and social care and, most importantly, building up medical services and relevant infrastructure suited to the needs of the elderly and the disabled. Nevertheless, such reallocation of funds from young-oriented programs to elderly-oriented ones may result in a future social income drop, and consequently have an adverse effect on rural area 
development. This is why, there is a pressing need to find solutions that will reverse or, at least, curb the above unfortunate tendencies. Solutions should be sought as part of the family-oriented policy, as only an increase in birth rates may slow down the ageing process.

\section{EDUCATION AND ECONOMIC ACTIVITY OF RURAL POPULATION IN POLAND}

The primary indicator of the quality of human capital is education (Kozera, 2011). The role of education as a factor allowing a multi-aspect development of rural areas and increasing absorption of European Union funds is emphasized in subject literature (Michałek, 2002). The level of knowledge determines entrepreneurship, which facilitates the search for new technological solutions and outlets, and improves agricultural farm management. On the other hand, the lower level of qualifications among farmers reduces their opportunity to meet set objectives (Nowak, 2009). A higher level of education brings about more than purely economic effects, such as changes to the awareness of rural populations. It promotes the feelings of greater autonomy and leads to active adaptation to changeable market conditions.

For many years now, there have been considerable disparities between the level of education of urban and rural populations (Table 3). The cited data indicate that in the year 2015 only $19.7 \%$ of the rural population - compared to $41.8 \%$ of the urban population - completed higher education. Furthermore, among people working in rural areas there were nearly three times as many primary and lower secondary level graduates as there were in cities and towns. This is a consequence of rural dwellers' impeded access to education, caused first and foremost by the financial situation of many rural households.

Table 3. Education of the working population in the years 2006-2015 (in \%)

\begin{tabular}{|c|c|c|c|c|c|c|c|c|c|c|}
\hline \multirow{2}{*}{$\begin{array}{c}\text { Level } \\
\text { of education }\end{array}$} & \multicolumn{5}{|c|}{ City/Town } & \multicolumn{5}{|c|}{ Countryside } \\
\hline & 2006 & 2010 & 2012 & 2014 & 2015 & 2006 & 2010 & 2012 & 2014 & 2015 \\
\hline Higher & 29.7 & 36.7 & 37.2 & 40.9 & 41.8 & 10.4 & 14.7 & 16.9 & 19.6 & 19.7 \\
\hline Secondary, post-secondary & 42.3 & 38.0 & 38.3 & 36.0 & 35.7 & 31.1 & 33.9 & 33.2 & 34.6 & 35.2 \\
\hline Basic vocational & 23.5 & 21.3 & 20.7 & 19.6 & 19.1 & 41.2 & 38.4 & 37.9 & 36.0 & 35.6 \\
\hline Lower secondary, primary & 4.4 & 4.0 & 3.8 & 3.5 & 3.4 & 17.2 & 13.0 & 12.1 & 9.9 & 9.5 \\
\hline
\end{tabular}

Source: own calculations based on (Aktywność ekonomiczna.... (Economic activity), 2016, p. 87)

However, rural population is not homogeneous in terms of completed education. Workers in the agriculture sector featured even lower levels of education than the rural landless. In the year 2015, the percentage of those involved in agriculture with higher education was only 5.3. This is in line with the thesis that there is an ongoing negative selection for the farming profession (Frenkel, 2013).

Without a doubt, a positive phenomenon noted in the Polish countryside is a systematic growth of the share of people with higher education and secondary and post-secondary education, and a downward tendency with regards to the population with primary and lower secondary education. This signifies growing educational aspirations of rural teenagers, primarily driven by career plans associated with non-agricultural sectors of economy (Sikorska, 2011).

However, the lower level of education reported in the rural population in Poland results in their lower socioeconomic activity, greater difficulties with finding an alternative position outside agriculture and low income levels referred to above (Marcysiak, 2005). Needless to say, the level of education significantly affects non-agricultural employment opportunities and active job seeking (Barefield, 2009). People of lower level of education are less professionally mobile and not highly active in terms of development of marketable skills. Typically, it is a lack of motivation or financial means for further education, which underlie the phenomenon.

Low qualifications of the rural dwellers constitute one of the most crucial barriers to overcoming unemployment and bringing economic revival to rural areas. This is confirmed by BAEL, according to which the number of employed rural dwellers has decreased from 678,000 in the end of 2012 to 517,000 in the end of 2015, i.e. by $23.7 \%$. What is more, a drop in the unemployed rural population was markedly larger in those having farms (by more than 1/4) than in the rural landless (by ca. 10\%). Along the decline in the absolute number of the unemployed, there was a decline in the unemployment rate: in 2015, it was 7.6\% compared to $14.3 \%$ in 2000 (Aktywność ekonomiczna...... (Economic Activity......), 2016)

When reviewing the economic activities of the rural population, we can see that in the year 2015 there were $6,842,000$ economically active people, which constituted $39.1 \%$ of the total economically active population in the country. In comparison with the year 1995, the number of economically active across rural areas has risen by 271,000 people. Nonetheless, the rural population economic activity rate in the analyzed period dropped from $60.5 \%$ to $56.3 \%$ (Table 4 ).

The decline in the economic activity rate across rural areas in the years 1995-2015 was the result of an over onemillion increase in economically inactive rural population. The nature of these changes demonstrates that the countryside is largely taking over the social functions. This, in turn, imposes an obligation to direct additional resources to rural areas in order to organize healthcare, social care and to facilitate communication and transport.

The group of economically active and employed in agriculture in the year 2015 was highly diversified in terms of demographic features and the quality of human capital (Table 5). The factors which differentiated human capital were: sex, age and the level of education. 
Table 4. Economic activity of people in the age range of 15 and more in Poland in 1995-2015

\begin{tabular}{|c|c|c|c|c|c|c|c|}
\hline \multirow{2}{*}{ Years } & \multirow{2}{*}{$\begin{array}{l}\text { Grand total } \\
\text { in thousand }\end{array}$} & \multicolumn{3}{|c|}{$\begin{array}{l}\text { Economically active } \\
\text { persons in thousand }\end{array}$} & \multirow{2}{*}{$\begin{array}{c}\text { Economically } \\
\text { inactive } \\
\text { persons in } \\
\text { thousand }\end{array}$} & \multirow{2}{*}{$\begin{array}{l}\text { Activity } \\
\text { rate in \% }\end{array}$} & \multirow{2}{*}{$\begin{array}{c}\text { Employment } \\
\text { rate } \\
\text { in } \%\end{array}$} \\
\hline & & Total & Working & Unemployed & & & \\
\hline \multicolumn{8}{|c|}{ CITY/TOWN } \\
\hline 1995 & 18248 & 10433 & 9001 & 1432 & 7815 & 57.2 & 49.3 \\
\hline 2000 & 19314 & 10768 & 8944 & 1852 & 8546 & 55.8 & 46.3 \\
\hline 2005 & 19613 & 10694 & 8834 & 1860 & 8919 & 54.5 & 45.0 \\
\hline 2010 & 19594 & 11004 & 9966 & 1038 & 8590 & 56.2 & 50.9 \\
\hline 2015 & 18804 & 10647 & 9955 & 692 & 8156 & 56.6 & 52.9 \\
\hline \multicolumn{8}{|c|}{ COUNTRYSIDE } \\
\hline 1995 & 10857 & 6571 & 5770 & 801 & 4287 & 60.5 & 53.1 \\
\hline 2000 & 11357 & 6532 & 5596 & 932 & 4825 & 57.5 & 49.3 \\
\hline 2005 & 11721 & 6589 & 5556 & 1033 & 5132 & 56.2 & 47.4 \\
\hline 2010 & 12147 & 6720 & 6109 & 611 & 5427 & 55.3 & 50.3 \\
\hline 2015 & 12159 & 6842 & 6324 & 518 & 5317 & 56.3 & 52.0 \\
\hline
\end{tabular}

Source: own calculations based on (Aktywność ekonomiczna.... (Economic activity), 2016).

Table 5. Indices representing economic activity of people in the age range of 15 and more in Poland in 2015 by sex, age and education

\begin{tabular}{|c|c|c|c|c|c|c|}
\hline \multirow{2}{*}{ Item } & \multicolumn{3}{c|}{ Economic activity rate } & \multicolumn{4}{c|}{ Employment rate } \\
\cline { 2 - 7 } & Total & Urban & Rural & Total & Urban & Rural \\
\hline Total & 56.5 & 56.6 & 56.3 & 52.6 & 52.9 & 52.0 \\
\hline Sex: Males & 65.0 & 64.4 & 66.0 & 60.6 & 60.2 & 61.3 \\
\hline Females & 48.6 & 49.8 & 46.7 & 45.2 & 46.6 & 42.9 \\
\hline Age: Working - mobile & 77.2 & 78.6 & 75.1 & 70.8 & 72.8 & 67.9 \\
\hline Working - immobile & 70.9 & 71.6 & 69.9 & 67.4 & 67.7 & 66.9 \\
\hline Education Higher & 80.8 & 80.4 & 82.3 & 77.9 & 78.0 & 77.7 \\
\hline Secondary Vocational & 64.8 & 60.0 & 73.1 & 60.6 & 56.4 & 68.3 \\
\hline Secondary General & 49.6 & 47.4 & 54.5 & 44.5 & 42.5 & 49.0 \\
\hline Basic vocational & 60.1 & 54.0 & 66.6 & 55.0 & 48.7 & 61.6 \\
\hline $\begin{array}{l}\text { Lower secondary \& } \\
\text { primary }\end{array}$ & 18.2 & 15.4 & 20.5 & 15.5 & 12.5 & 18.0 \\
\hline
\end{tabular}

Source: own calculations based on (Aktywność ekonomiczna.... (Economic activity), 2016, pp. 69-73).

The analysis showed that a higher activity rate was reported in males. In the case of rural areas in the year 2015, the difference was 19.3 percentage points (in the cities/towns it was 14.6 percentage points). A similar correlation was noted with regards to employment rates. The working - mobile age persons were more active than the working - immobile population. Still, the most significant differentiating factor was the level of education. In the case of people with higher education, the activity rate was above $80 \%$ for both the city/town dwellers and the rural dwellers; with the employment rate above $77 \%$. A decrease in the level of education showed a decline in the economic activity of the population. However, the reported tendency did not affect people with secondary level general education. These persons, both living in rural and urban areas, were less economically active and found employment less often than those with basic vocational education. This argues in favor of investing in public education at both higher and vocational levels. Investment in education is an opportunity for rural areas not only to reduce the disparities between the city/town and the countryside with regards to education, and to boost economic activity of the rural dwellers, but most of all to develop high quality human capital. In order to seize the opportunity, one needs to take actions aiming at: redressing the educational balance in favor of rural population, enhancing the quality of education across rural areas, and creating conditions allowing rural population to become economically involved in non-agricultural activities (combating unemployment). All actions taken at both national and regional levels, aiming at increasing qualifications of rural (including agricultural) population, contribute to an increase in intellectual potential and competitiveness of the country and its individual regions.

\section{CONCLUSIONS}

At present, nearly $40 \%$ of the total Polish population inhabit rural areas. The size of rural human resources is affected not only by the transformations of the country's demographics, including the process of population ageing, internal and external migrations, but also by changes in quality potential. Recently, there has been an increase in the number of people inhabiting the rural areas due to a positive internal migration balance, particularly dynamic in the vicinity of large urban agglomerations. Hence, it may be stated that human capital resources across rural areas in Poland are significant. Nonetheless, from the point of view of economic development, it is not only the quantity that matters, but also and above all the quality of said resources, expressed by the level of education, economic activity, and others. In this context, the beneficial transformations of the rural human resources with regards to the level of education should be evaluated positively. The rise in the level of education and economic activity may accelerate the favorable transformations of the area structure of agricultural farms, for it contributes to the acceleration of migration 
of the rural population to other, non-agricultural professions. Even though the ability of individuals, regions and countries to take advantage of the emerging knowledge-based economy largely depends on their human capital, continuous improvement by way of education and trainings, now considered to be increasingly more important factors of economic growth, still plays an important role.

One striking fact, however, is that rural population, quite like the total Polish population, is undergoing the process of demographic ageing and that peripheral rural areas are threatened with de-population. The adverse demographic transformations affecting the structure of the rural population may seriously impede its growth. The ageing of rural communities involves the risk of limiting economic activities of this population, and at the same time, also a decrease in their economic autonomy and an increase in social burden resulting therefrom. A crucial area of state's intervention seems here to be an extension and stimulation of economic activity of the elderly. It is necessary to fight the tendency of professional and social withdrawal presented by older people by the provision of suitable institutional and legal conditions.

All in all, the underlying challenge in the $21^{\text {st }}$ century for both the countries and the regions is to build knowledgebased economies, wherein human capital plays the key role. The evolving nature of rural areas, i.e. the shrinking agricultural land resources and the growing importance of the residential, tourist, and recreational functions, bring multiple challenges, the generator of which is, indeed, human capital. Both state and local authorities should, therefore, make every effort to use the capital in the best manner possible, by seizing opportunities and preventing threats. In the context of the outlined trends, a conclusion may be drawn that rural area development will increasingly depend on the stimulation of human capital growth via investment in education and on the ability to ensure correct use of human resources by creating conditions favoring working life prolongation.

\section{REFERENCES}

1. Aktywność ekonomiczna ludności Polski (Economic activity of the Polish population). 2016. GUS, Warszawa. [In Polish]

2. Avramov, D., Maskova, M. 2003. Active ageing in Europe. Population Studies, 41, Vol. 1, Council of Europe Publishing.

3. Barefield, A., 2009. Discussion: Human Capital and Rural Economic Development. Journal of Agricultural and Applied Economics, Vol. 41, Iss. 2, pp. 431-433. https://doi.org/10.1017/S107407080000290X

4. Becker, G.S. 1993. Human Capital. A Theoretical and Empirical Analysis with Special Reference to Education, University of Chicago Press. https://doi.org/10.7208/chicago/9780226041223.001.0001

5. Benhabib, J., Spiegel, M. 2005. Human Capital and Technology Diffusion, [in:] Aghion P., Durlauf, P.S. (eds.), Handbook of Economic Growth, Amsterdam.

6. Bollman, R.D.1999. Human Capital and Rural Development: What Are the Linkages? Agriculture and Rural Working Paper Series 28025, Statistics Canada.

7. Caroleo, F.E., Pastore, F. 2010. Structural Change and Regional Labour Market Imbalances in Transition, [in:] E. Marelli, M. Signorelli, Economic Growth and Structural Features of Transition, Palgrave Macmillan. https://doi.org/10.1057/9780230277403_13

8. Chechelski, P., Grochowska, R., Wigier, M. 2012. Wyzwania i ograniczenia długookresowego rozwoju rolnictwa i obszarów wiejskich w Polsce (Challneges and limitations of long-term development of agriculture and rural areas in Poland), Instytut Rolnictwa i Gospodarki Żywnościowej - PIB, Warszawa. [In Polish]

9. Clark R.L., Spengler, J. J. 1985. Changing Demography and Dependency Costs: the Implications of Future Dependency Rations and Their Composition, [in:] Ageing and Income, B. Rieman Herzog (ed.), N. York, London, quoted on the basis of: Wierchowski, S. 1999. Demograficzne aspekty procesu starzenia sie ludności Polski. (Demographic aspects of the ageing of the Polish population) Ruch Pracowniczy Ekonomiczny i Socjologiczny, Rok LXI — zeszyt 1, pp. 19-56. [In Polish]

10. Cooke, P. 1992. Regional Innovation Systems: Competitive Regulation in the New Europe, Geoforum. https://doi.org/10.1016/0016-7185(92)90048-9

11. Crafts, N. 1996. Post - Neoclassical Growth Theory. What are its policy implications? Oxford Review of Economic Policy, Vol. 12, pp. 30-47. https://doi.org/10.1093/oxrep/12.2.30

12. Domański, S.R. 1993. Kapitał ludzki i wzrost gospodarczy (Human capital and economic growth), PWN, Warszawa. [In Polish]

13. Frenkel, I. 2013. Zatrudnienie i struktura dochodów w gospodarstwach rolnych w latach 2005-2010 (Employment and income structure in agriculture holdings), IRWiR PAN, Warszawa. [In Polish]

14. Frenkel, I. 2016. Polska wieś 2016. Raport o stanie polskiej wsi (Polish countryside 2016. Report on the situation of the Polish countryside), [in:] Wilkin, J., I Nurzyńska, I. (eds.), Wydawnictwo Naukowe SCHOLAR, Warszawa. [In Polish]

15. Fukuyama, F. 1997. Zaufanie. Kapitał społeczny a droga do dobrobytu (Trust. Social capital and the road to prosperity), PWN, Warszawa-Wroctaw. [In Polish]

16. Jurajda S., Terrell K..2009. Regional unemployment and human capital in transition economies. Economics of Transition, Vol. 17, Iss. 2, pp. 241-274. https://doi.org/10.1111/j.1468-0351.2009.00351.x

17. KozerA, M. 2011. Jakość zasobów ludzkich na obszarach wiejskich (Quality of rural human resources). Problemy Rolnictwa Światowego. Zeszyty Naukowe SGGW w Warszawie, Vol. 11/26, No. 4, pp. 109-118. [In Polish]

18. Lucas, R.E. 2004. Life earnings and rural-urban migration. Journal of Political Economy, Vol. 112, pp. $29-59$. https://doi.org/10.1086/379942

19. Makowski, K. 2002. Instrumentarium zarzadzania zasobami ludzkimi (Set of instruments for human resource management), Wyd. Szkoły Głównej Handlowej, Warszawa. [In Polish] 
20. Mankiw, N.G., Romer, D., Weil, D.N. 1992. A contribution to the empirics of economic growth. Quarterly Journal of Economics, Vol. 107, pp. 407-437. https://doi.org/10.2307/2118477

21. Marcysiak, A. 2005. Czynniki kształtujące aktywność ekonomiczną ludności w gospodarstwach indywidualnych (Factors shaping economic activity of individual holdings). Prace Komisji Nauk Rolniczych i Biologicznych, Vol. B, No. 57, Bydgoszcz, pp. 445-452. [In Polish]

22. Markowska-Przybyła, U. 2004. Kapitał ludzki i kapitał społeczny jako determinanty zdolności konkurencyjnej regionu (Human capital and social capital as determinants of regional competitive capacities). Prace Naukowe Akademii Ekonomicznej we Wrocławiu, No. 1031, Vol. 1, pp. 253-270. [In Polish]

23. Michałek, R. 2002. Wiedza - najefektywniejszą drogą restrukturyzacji polskiego rolnictwa (Knowledge - the most effective road to Polish agriculture restructuring). Problemy Inżynierii Rolniczej, Vol. 2, pp. 5-13. [In Polish]

24. Nowak, A. 2009. Kwalifikacje rolników czynnikiem rozwoju gospodarstw rolnych (Farmers' qualifications as a growth factor for agricultural holdings). Acta Scientiarum Polonorum Oeconomia, No. 8(3), pp. 107-116. [In Polish]

25. OECD. 2007. Human Capital: How what you know shapes your life. Available at https://www.oecd.org/insights/38435854.pdf (Accessed on 12/09/2017).

26. Prognozy ludności Polski na lata 2004-2050 (Projection of Polish population for the years 2004-2050). 2014. GUS, Warszawa. [In Polish]

27. Reher, D.S. 2004. The Demographic Transition Revisited as a Global Process. Population, Space and Place, Vol. 10, pp. $19-41$. https://doi.org/10.1002/psp.313

28. Rocznik Demograficzny 2016 (Demographic Yearbook 2016). 2016. GUS, Warszawa. [In Polish]

29. Rocznik statystyczny 2001, 2002. (Statistical Yearbook 2001, 2002) GUS, Warszawa. [In Polish]

30. Rogers, M. 2003. A Survey of Economic Growth. The Economic Record, Vol. 79, No. 244, pp. $112-135$. https://doi.org/10.1111/1475-4932.00082

31. Romer, P.M. 1990. Endogenous Technological Change. Quarterly Journal of Economics, Vol. 98, pp. 71-102. https://doi.org/10.1086/261725

32. Sachs, J.D. 2001. Macroeconomics and Health: Investing in Health for Economic Development. Report of the Commission on Macroeconomics and Health, WHO, Geneva 2001.

33. Sikorska, A. 2011. Uwarunkowania rozwoju kapitału ludzkiego w rolnictwie i na obszarach wiejskich (Preconditions of human capital development in agriculture and rural areas) IERiGZ Warszawa.

34. Solow, R. 1956. A contribution to the Theory of economic growth. Quarterly Journal of Economics, Vol. 70, pp. 65-94. https://doi.org/10.2307/1884513

35. Storper, M.1995. The Resurgence of Regional Economics, Ten Years Later: The Region as a Nexus of Untraded Interdependencies. European Urban and Regional Studies, Vol. 2, No. 3, pp. 191-221. https://doi.org/10.1177/096977649500200301

36. Zsarnòczky, M. 2016. The impact of silver tourism on rural areas. Roczniki Naukowe Stowarzyszenia Ekonomistów Rolnictwa $i$ Agrobiznesu, Vol. XVIII, No. 3, pp. 402-409. 